\title{
ENERGY PERFORMANCE OF HYDROCARBON REFRIGERANT AS A POSSIBLE ALTERNATIVE REFRIGERANT TO R134A IN DOMESTIC REFRIGERATORS
}

\author{
Tamer M. Hassan ${ }^{1}$, N. A. Mahmoud ${ }^{1}$ and M. S. El-Morsi ${ }^{2}$ \\ ${ }^{1}$ Ain Shams University, Faculty of Engineering, Mechanical Power Engineering Department \\ ${ }^{2}$ Department of Mechanical Engineering, American University in Cairo
}

\begin{abstract}
The performance of a domestic refrigerator is theoretically assessed in this study. The refrigerator utilizes R1234yf as an alternative refrigerant for R134a. The performance is evaluated for three condensing temperatures, specifically, 30,40 , and $50^{\circ} \mathrm{C}$ at different evaporator temperatures, ranging -30 and $0^{\circ} \mathrm{C}$. The performance of the refrigerator is compared in terms of volumetric cooling capacity, coefficient of performance, compressor power consumption and discharge temperature. The results of the study confirm that R1234yf is an efficient and environment-friendly substitute for R134a that can be used in domestic refrigerators.
\end{abstract}

Key Words: Refrigerant, Hydrocarbon, R134a, Energy and Domestic refrigerator

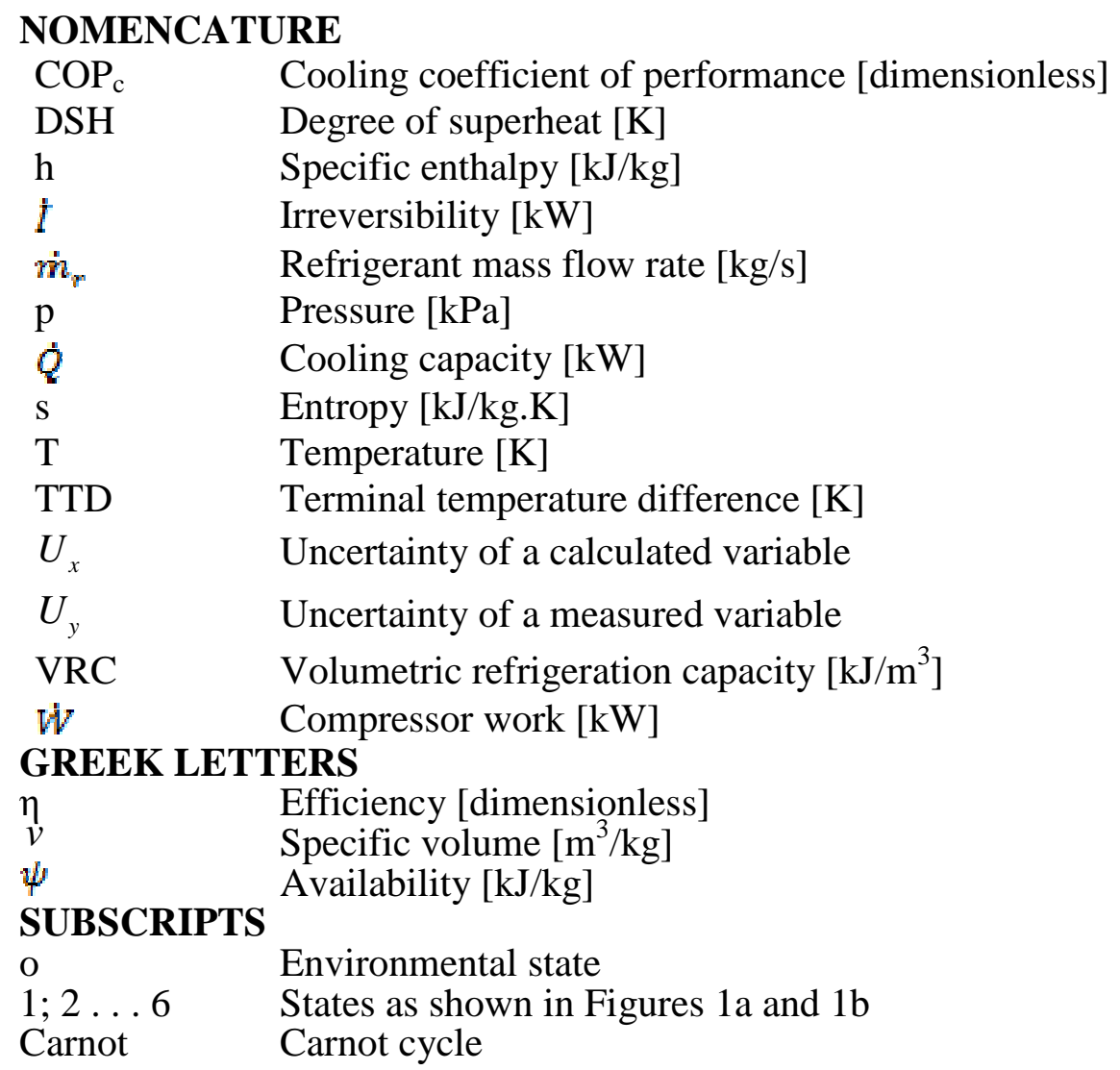




$\begin{array}{ll}\text { comp } & \text { Compressor } \\ \text { cond } & \text { Condenser } \\ \text { el } & \text { Electric motor } \\ \text { evap } & \text { Evaporator } \\ \text { ex } & \text { Exergy } \\ \text { exp } & \text { Expansion valve } \\ \text { is } & \text { Isentropic } \\ \text { mech } & \text { Mechanical } \\ \text { ABBREVIATIONS } \\ \text { CFC } & \text { Chlorofluorocarbon } \\ \text { DSH } & \text { Degree of superheat } \\ \text { GHG } & \text { Greenhouse gases } \\ \text { GWP } & \text { Global warming potential } \\ \text { HC } & \text { Hydrocarbon } \\ \text { HCFC } & \text { Hydrochlorofluorocarbon } \\ \text { HFC } & \text { Hydrofluorocarbon } \\ \text { HFO } & \text { Hydrofluoroolefin } \\ \text { LPG } & \text { Liquefied petroleum gas } \\ \text { LSHX } & \text { Liquid-suction heat exchanger } \\ \text { ODP } & \text { Ozone depletion potential } \\ \text { INTRODUCTION }\end{array}$

During 1900's, chlorofluorocarbons (CFCs) and hydrochlorofluorocarbons (HCFCs) were extensively used in refrigeration and air conditioning vapor compression systems. When their ozone-depleting potential became recognized, the Montreal Protocol was adopted by many nations to begin the phase out of both CFCs and HCFCs [1]. So, hydrofluorocarbons (HFCs) were developed as a long-term alternative to substitute CFCs and HCFCs, and while they were non-ozone depleting, they did have large global warming potential (GWP). In 1997, HFCs were considered as greenhouse gases (GHGs) and currently they are target compounds for GHG emission reduction under the Kyoto Protocol [2]. One of those refrigerants is R134a, with a GWP (100 years) of 1430, extensively used in refrigeration and air conditioning. In this way, the growing international concern over relatively high GWP refrigerants has motivated the study of low GWP alternatives for HFCs in vapor compression systems, [3], [4]. The main candidates to replace R134a in vapor compression systems are natural refrigerants like ammonia, carbon dioxide or hydrocarbons (HC) mixtures; low GWP HFCs, and hydrofluoroolefin (HFO), specifically R1234yf, [5]-[7]. The use of hydrocarbons (HCs), offers a good drop-in replacement for halogenated refrigerants in terms of environmental impacts and energy consumption, [8]. However, the main disadvantage of the implementation of hydrocarbons mixtures is their flammability [9].

For the case of drop-in in domestic refrigeration with medium-class flammability refrigerants, like R152a and R32, the average COP obtained using R152a is higher than the one using $\mathrm{R} 134 \mathrm{a}$, while the average COP of R32 is lower than the one using R134a [10]. R1234yf was proposed as a replacement for R134a in mobile air conditioning systems [11], [12], and its similar thermo-physical properties makes R1234yf a good choice to replace R134a in other applications of refrigeration and air conditioning.

Focusing on R1234yf, this refrigerant does not contain chlorine, and therefore its ODP is zero and its GWP is as low as 4 [13], [14]. About security characteristics, R1234yf has low toxicity, similar to R134a, and mild flammability, significantly less than R152a [15]. Several research works can be found in the literature presenting theoretical studies to determine the feasibility of direct substitution (or with slight modifications) using R1234yf in facilities working with R134a being most of them based on mobile air conditioning systems, [5], [16], [17].

Belman at al [5], presented an experimental study for three identical domestic refrigerators using R1234yf as a drop-in replacement for R134a. The optimal charge for R1234yf was about $7.8 \%$ lower than the one for R134a, which represents a small increase of $4 \%$ in energy consumption in comparison to R134a. Sotomayor and Parise [12] developed a compressor model for an air conditioning system which simulates the operation working with R1234yf, R134a and R290. Shi et al. [16] experimentally studied the performances of R1234yf as a 
drop-in replacement for R134a. Under different working conditions the cooling capacity increased by $11.3 \%$ and the coefficient of performance (COP) increased by $8 \%$. Cho and Park [11], performed an exergy analysis for different compressor speeds in an automotive air conditioning system using R1234yf and R134a. The R1234yf system had a smaller cooling capacity and lower COP compared to the R134a system. In addition, the R1234yf system showed a lower second law efficiency at all compressor speeds. Jankovic et al. [17] characterized and validated a low power refrigeration system, by assessing the performances for R1234yf, R1234ze(E) and R134a under different operational conditions. Their results showed that R1234yf was an adequate drop-in for R134a, but R1234ze(E) may perform better when an over-ridden compressor is used to match the refrigerant system cooling power. Sethi et al. [18] analyzed both theoretically and experimentally a vending machine, which used R1234yf. They concluded that, based on actual drop-in system testing, the R1234yf showed capacity and efficiency similar to that of R134a. Aprea et al. [6] experimentally evaluated a domestic refrigerator using R1234yf as a substitute for R134a. Their investigation was based on comparing the energy performance among both refrigerants. In addition, through a pulldown test, they obtained an optimal charge of $10 \%$ higher than with R134a; such analysis was performed without any modification to the vapor compression cycle.

Recently, Aprea et al. [7] presented another experimental analysis among R134a, R1234yf and refrigerant mixture of R134a/R1234yf (10/90\% weight), in domestic refrigerators. Their results showed that the refrigerant mixture was the best drop-in refrigerant for R134a. In addition, the mixture lead to a reduction in the electrical energy consumption during the pulldown tests by about 7.5 and $10 \%$ as compared to R134a and R1234yf, respectively. Sieres and Santos [19] experimentally studied the use of R1234yf as a drop-in replacement for $\mathrm{R} 134 \mathrm{a}$ in a small power vapor-compression refrigeration system. The performance is assessed for two compressor frequencies 40 and $60 \mathrm{~Hz}$, at evaporator temperatures, between -5 to $5^{\circ} \mathrm{C}$. Three condensing temperatures were considered, specifically, 45,50 , and $55^{\circ} \mathrm{C}$. Their results show that R1234yf was an adequate drop-in refrigerant for R134a. Meng et. al [20] experimentally studied the use of R1234yf/R134a (89:11 wt) as an alternative to R134a in automotive air conditioning systems using micro-channel heat exchangers in cooling and heating modes. Their results show that R1234yf/R134a can be used as an environmentfriendly replacement for R134a in automotive air conditioning systems, with minor modifications.

Regarding flammability, Needham and Westmoreland [21] developed a comprehensive chemical mechanism to describe combustion of R1234yf. Feng et. al [22] experimentally studied the influence of two kinds of flame retardants on the flammability of R1234yf. The flammability limits of R1234yf and the mixtures of R1234yf/R227ea and R1234yf/R134a were tested based on ASTME 681 and ASHRAE standard 34. They concluded that the addition of the flame retardants had a more pronounced effect on the flammability limit of R1234yf than flame characteristics.

The above researches show that R1234yf is an ideal drop-in replacement for R134a. In most results, small increases in energy consumption was observed when using R1234yf in comparison with R134a. Regarding the application of R1234yf in domestic refrigerators, it is worth to say that there is not enough information available, restricted to energy evaluation when comparing the conventional refrigerant R134a with R1234yf; these evaluations were performed under specific operational conditions and with some design modifications. In an effort to continue and to extend previous studies in the field of household appliances, this paper presents the details of a theoretical study for R1234yf as a drop-in replacement for refrigerant $\mathrm{R} 134 \mathrm{a}$ in a domestic refrigerator.

The aim of this work is to present a theoretical study for R1234yf as a drop-in replacement for refrigerant R134a in a vapor compression system under a wide range of working conditions. An energetic characterization with both refrigerants is carried out using, as main performance parameters, the volumetric cooling capacity, the compressor power consumption, the COP, the total irreversibility, the exergetic efficiency and the second law efficiency. 


\section{CHARACTERISTICS OF R134A AND R1234YF}

Figures 1-4 compares the properties of R134a and R1234yf for temperature range $-40-80$ $\left[{ }^{\circ} \mathrm{C}\right]$. Figure 1 presents the variation of vapor pressure with temperature for both refrigerants. The figure shows that both R1234yf and R134a have nearly the same vapor pressures at lower temperatures. However, the figure shows that at higher temperatures, the vapor pressure of R1234yf is marginally lower than that of R134a. Hence the compressors can operate at relatively lower pressures. Figure 2 presents the variation of the latent heat with temperature for both refrigerants. The figure shows that, within the studied temperature range, the latent heat of R1234yf is 17-26\% lower than that of R134a. The lower latent heat of R1234yf causes a decrease in the system's refrigeration capacity. As a result, the compressor running time increases.

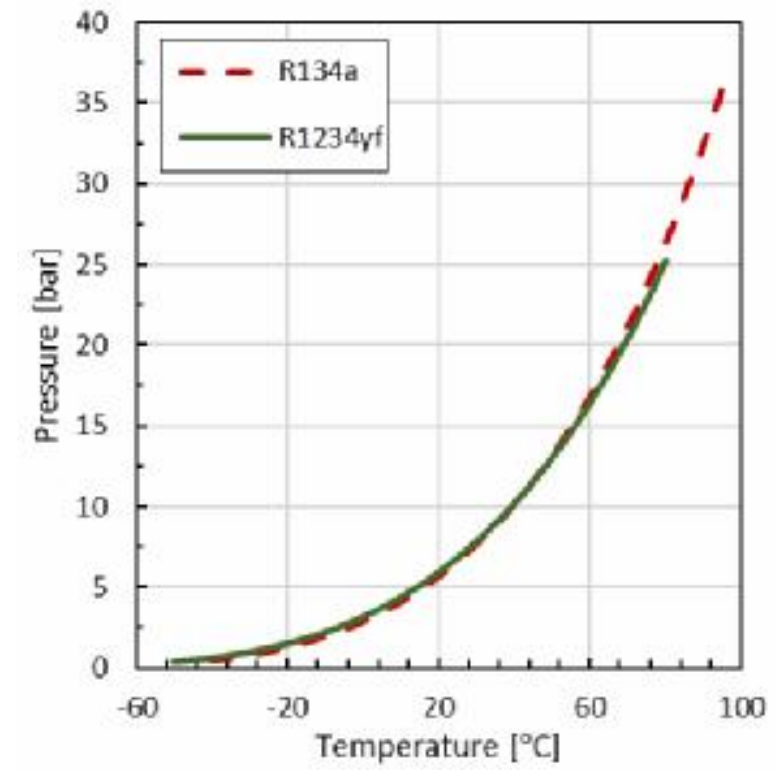

Figure 1:

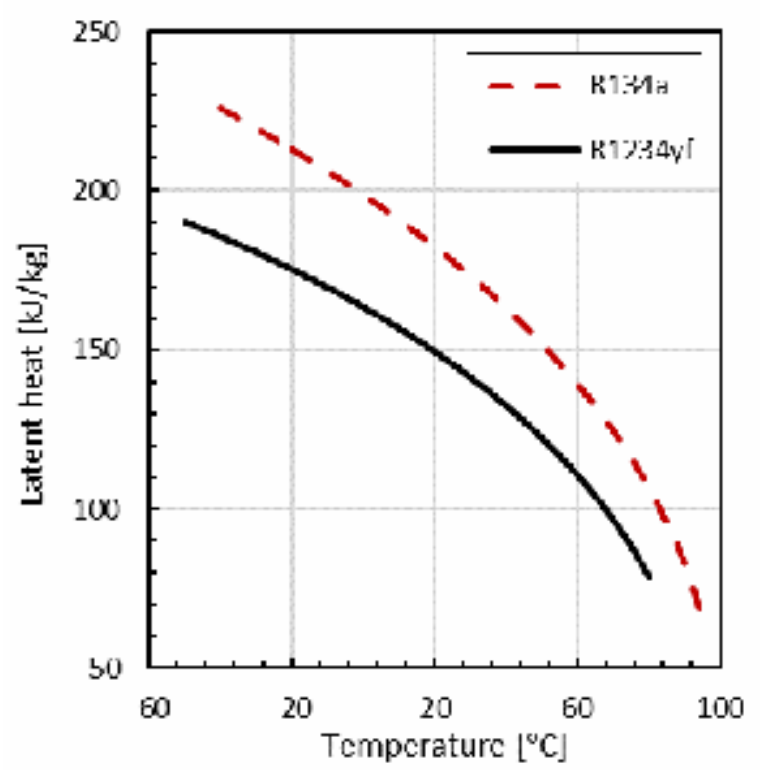

Figure 2: Variation of latent heat with temperature

Figure 3 illustrates the variation of liquid viscosity with temperature for both refrigerants. The figure shows that the liquid viscosity of R1234yf is lower than that of R134a, within the studied temperature range. This results in lower friction (lower irreversibility) and hence a lesser amount of power can be expected with R1234yf. Figure 4 compares the variation of liquid densities, of both refrigerants, with temperature.

The figure shows that the liquid density of R1234yf is lower than that of R134a by about 9$13 \%$. This will result in a significant reduction in the refrigerant charge requirement. The critical temperature and pressure, boiling point, molecular weight, ODP and GWP are compared in Table 1. The table shows that R1234yf has zero ODP and low GWP, [23]. Also, the critical temperature and pressure of R1234yf are lower than those of R134a. 


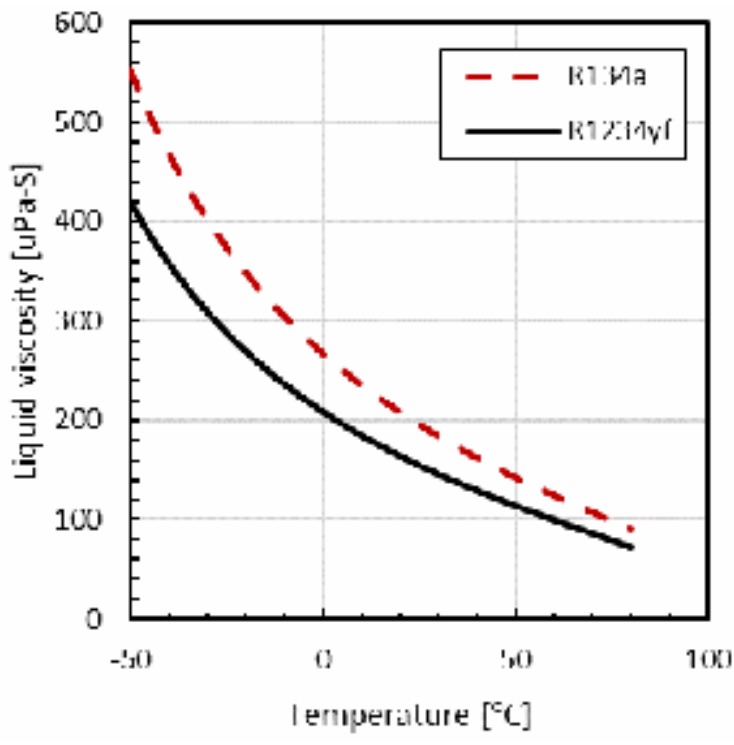

Figure 3: Variation of liquid viscosity with temperature

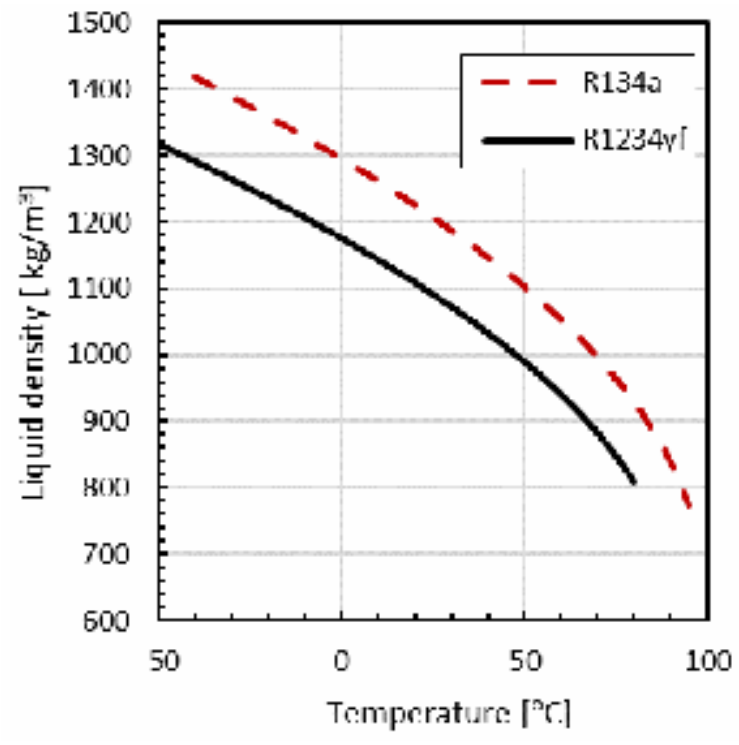

Figure 4: Variation of liquid density with temperature

Table 1: Properties of 134a and R1234yf [23], [24]

\begin{tabular}{|l|c|c|c|c|c|c|}
\hline Refrigerant & $\begin{array}{c}\text { Boiling } \\
\text { Point }\end{array}$ & $\begin{array}{c}\text { Molecular } \\
\text { Weight }\end{array}$ & $\begin{array}{c}\text { Critical } \\
\text { Temperature }\end{array}$ & $\begin{array}{c}\text { Critical } \\
\text { Pressure }\end{array}$ & ODP & GWP \\
\hline$\left[{ }^{\circ} \mathbf{C}\right]$ & {$[\mathbf{g} / \mathbf{m o l}]$} & {$\left[{ }^{\circ} \mathbf{C}\right]$} & {$[$ bar $]$} & & \\
\hline R134a & -26.4 & 102.03 & 101.1 & 40.6 & 0 & 1430 \\
\hline R1234yf & -29.45 & 114.04 & 94.7 & 33.82 & 0 & 4 \\
\hline
\end{tabular}

\section{THERMODYNAMIC ANALYSIS}

Figure 5a depicts a schematic diagram for the vapor compression refrigeration cycle under investigation. While Figure $5 \mathrm{~b}$ presents the pressure-enthalpy diagram for the cycle showing the liquid sub-cooling and vapor super heating. Usually, sub-cooling and super heating improves the performance of vapor compression-based refrigeration systems utilizing pure and

mixed refrigerants [10]. 


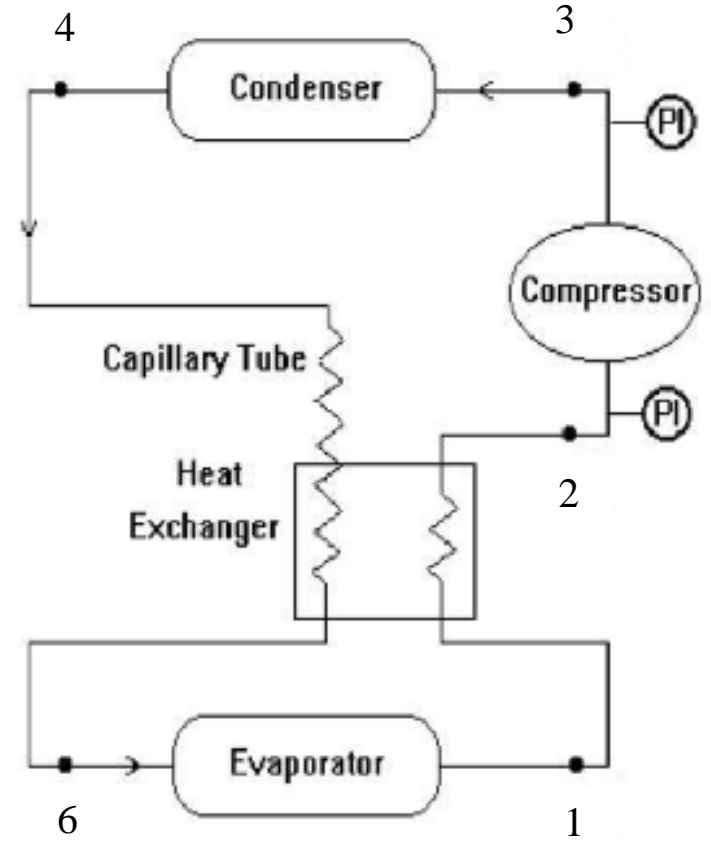

Figure 5a: Schematic diagram of a vapor compression refrigeration cycle used in domestic refrigerators

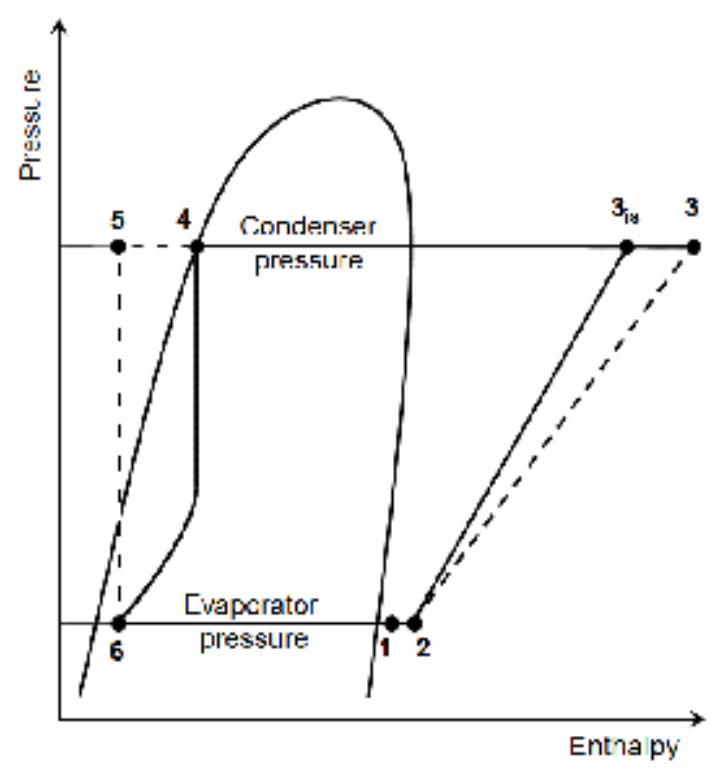

Figure 5b: Pressure enthalpy diagram with liquid sub cooling and vapor super heating

Processes 2-3, 3-4, 4-6 and 6-1 represent the different cycle processes, such as compression, condensation, expansion and evaporation, respectively. Processes 1-2, and 4-5 represent the superheating and sub-cooling processes, respectively. States 2, 3, 4 and 6 represent the thermodynamic states of the refrigerant at the compressor inlet (superheated vapor at evaporator pressure), compressor outlet (superheated vapor at condenser pressure), condenser outlet (sub cooled liquid at condenser pressure) and evaporator inlet (two-phase fluid at the evaporator pressure), respectively. The performance of the system is evaluated theoretically in terms of the first and second law of thermodynamics. The following assumptions are made:

1. Steady-state operation in all components.

2. Pressure losses through pipelines are neglected.

3. Compressor isentropic, mechanical and electric motor efficiencies are considered.

4. Pressure drop at compressor inlet and exit are neglected.

5. Degree of superheat at the evaporator exit (DSH) is $3[\mathrm{~K}]$.

6. Degree of sub-cooling at the condenser exit is $0[\mathrm{~K}]$.

The property values obtained from ESS, [25], have been used for predicting the performance of the refrigerants. The first and second laws of thermodynamics are applied on every component of the cycle yielding the following sets of equations, [26], [27]. 


\section{Evaporator}

$\dot{Q}_{\text {evap }}=\dot{m}_{r}\left(h_{1}-h_{6}\right)$

The volumetric refrigeration capacity is defined by equation (2),

$$
V R C=\frac{\dot{m}_{r}\left(h_{1}-h_{6}\right)}{v_{2}}
$$

where $v_{2}$ is the specific volume at the compressor inlet. The pressure ratio $P_{p}$ is calculated from equation (3),

$$
P_{r}=P_{\sigma} / P_{\theta}
$$

where $P_{\varepsilon}$ and $P_{q}$ are the condenser and evaporator pressures, respectively. The irreversibility of the evaporator is defined by equation (4) as

$$
\dot{I}_{\text {wap }}=\dot{m}_{r}\left(\psi_{6}-\psi_{1}\right)+\dot{Q}_{\text {wusp }}\left(1-T_{\alpha} / T_{\text {ewap }}\right)
$$

where the $\psi$ is the availability (exergy) defined by equation (5) as

$\psi=\left(h-h_{o}\right)-T_{o}\left(s-s_{o}\right)$

\section{Compressor}

$\dot{W}_{\text {casmp }}=\dot{m}_{r}\left(h_{3}-h_{2}\right)$

where $h_{3}$ is the enthalpy following a real compression process defined by equation (7).

$h_{3}=\frac{h_{3, \text { is }}-h_{2}}{\eta_{\text {is }}}+h_{2}$

where $h_{3}$,is is the enthalpy following an isentropic compression process and $\eta_{\text {is }}$ is the compressor isentropic efficiency, given in Table 2. The compressor electric motor power consumption is defined by equation (8). 
$\dot{W}_{e I}=\frac{\dot{W}_{c o s p p}}{\eta_{m e c h} \eta_{e l}}$

where $\eta_{\text {mech }}$ and $\eta_{\mathrm{el}}$ are the compressor mechanical and the electric motor efficiencies, respectively, given in Table 2. The irreversibility of the compressor is defined by equation (9) as

$\hat{I}_{\text {cossp }}=\dot{m}_{F}\left(\psi_{2}-\psi_{3}\right)+\dot{W}_{e l}$

Condenser

$\dot{Q}_{\text {cond }}=\dot{m}_{r}\left(h_{3}-h_{4}\right)$

The irreversibility of the condenser is defined by equation (11) as

$\dot{I}_{\text {cond }}=\dot{m}_{r}\left(\psi_{3}-\psi_{4}\right)+\dot{Q}_{\text {cond }}\left(1-T_{o} / T_{\text {cond }}\right)$

Expansion valve

The irreversibility of the expansion valve is defined by equation (12) as

$\hat{l}_{\exp }=\dot{m}_{r}\left(\psi_{4}-\psi_{6}\right)$

Liquid-suction heat exchanger

$\dot{Q}_{L S H X}=\dot{m}_{r}\left(h_{4}-h_{6}\right)=\dot{m}_{r}\left(h_{2}-h_{1}\right)$

The irreversibility of the LSHX is defined by equation (14) as

$\dot{I}_{L S H X}=\dot{m}_{r}\left(\psi_{4}-\psi_{6}\right)+\dot{m}_{r}\left(\psi_{1}-\psi_{2}\right)$

The coefficient of cooling performance $\left(\mathrm{COP}_{c}\right)$ of the cycle is defined by equation (15) as

$C O P_{c}=\frac{\dot{Q_{g v g p}}}{\dot{W}_{e l}}$ 
The total irreversibility $\left(I_{\text {total }}\right)$ of the cycle is defined by equation (16) as

$\dot{I}_{\text {tatal }}=\dot{I}_{\text {evap }}+\dot{I}_{\text {comp }}+\dot{I}_{\text {cond }}+\dot{I}_{\text {exp }}+\dot{I}_{L S H X}$

The exergy efficiency of the cycle is defined by equation (17), [27] as

$\eta_{\mathrm{m}}=\frac{\dot{m}_{r}\left(\psi_{1}-\psi_{6}\right)}{\dot{W}_{\mathrm{el}}}$

The second law efficiency of the cycle is defined by equation (18), [27] as

$\eta_{2 \mathrm{nd}}=\frac{\mathrm{COP}_{\mathrm{c}}}{\mathrm{COP}_{\text {Carnot }}}$

where $C O P_{\text {Carnot }}$ is the Carnot efficiency, defined by equation (19) as

$\mathrm{COP}_{\text {Carnot }}=\frac{T_{\text {evap }}}{\left(T_{\text {cond }}-T_{\text {evap }}\right)}$

Table 2 Operating conditions of the refrigeration system.

\begin{tabular}{|l|l|}
\hline Reference temperature $\left(T_{\mathrm{o}}\right)$ & $293[\mathrm{~K}]$ \\
\hline Reference pressure $\left(p_{\mathrm{o}}\right)$ & $100[\mathrm{kPa}]$ \\
\hline Refrigeration capacity $\left(\dot{Q}_{\mathrm{zvag}}\right)$ & $1[\mathrm{~kW}]$ \\
\hline Evaporator temperature range $\left(T_{\text {evap }}\right)$ & $243-273[\mathrm{~K}]$ \\
\hline Condenser temperature range $\left(T_{\text {cond }}\right)$ & $303-323[\mathrm{~K}]$ \\
\hline Degree of sub-cooling in the condenser $(\mathrm{DSC})$ & $0[\mathrm{~K}]$ \\
\hline Degree of superheat in the evaporator $(\mathrm{DSH})$ & $3[\mathrm{~K}]$ \\
\hline Temperature rise for vapor in LSHX & $3[\mathrm{~K}]$ \\
\hline Compressor isentropic efficiency $\left(\eta_{\text {is }}\right)$ & $80 \%$ \\
\hline Compressor mechanical efficiency $\left(\eta_{\text {mech }}\right)$ & $90 \%$ \\
\hline Electric motor efficiency $\left(\eta_{\mathrm{el}}\right)$ & $90 \%$ \\
\hline
\end{tabular}

RESULTS AND DISCUSSIONS

This section presents the results of the theoretical study. The study is performed at three condensing temperatures, specifically, 30,40 , and $50^{\circ} \mathrm{C}$ and at different evaporator temperatures, ranging -30 and $0^{\circ} \mathrm{C}$. The condenser temperature range covers normal, subtropical and tropical climatic conditions against wide range of evaporator temperatures, which covers different thermostat settings in the refrigerator. The assessment of the refrigerator was made according to ISO 8187 [28].

Variation of refrigerant mass flow rate

in Figure 6a. presents the variation of the refrigerants mass flow rate at different evaporator temperatures at a condenser temperature of $40^{\circ} \mathrm{C}$. The figure shows that the mass flow rate of R1234yf is higher than that of R134a by about 29-38\%. This can be attribute to its lower liquid density. As a result, a higher compressor power can be anticipated with R1234yf. The same observation for the mass flow rate is depicted at an evaporator temperature of $-10^{\circ} \mathrm{C}$, higher mass flow rate for R1234yf, as shown in Figure $6 \mathrm{~b}$. 


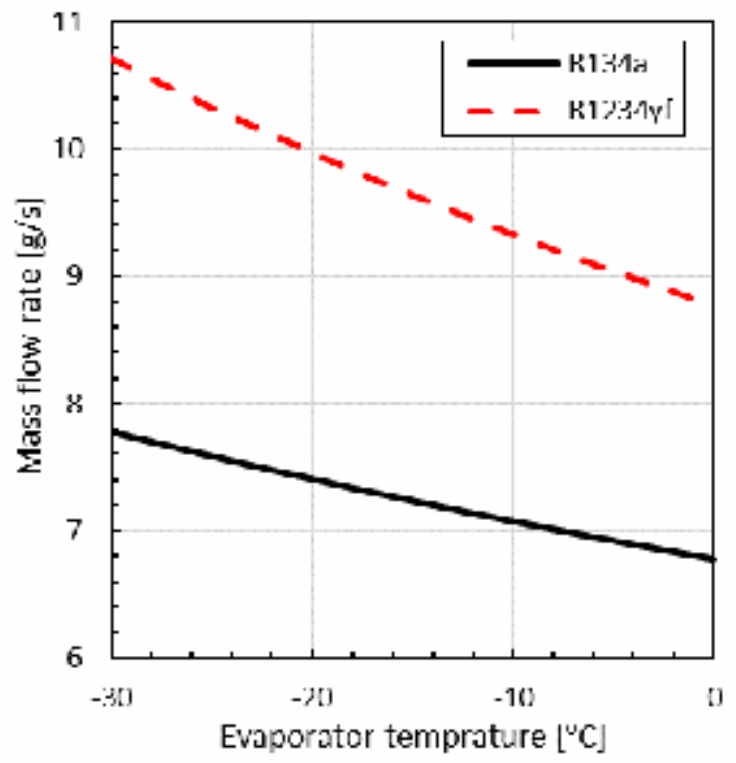

Figure 6a: Variation of the refrigerant mass flow rate with the evaporator temperature at $\mathrm{T}_{\text {cond }}=40^{\circ} \mathrm{C}$

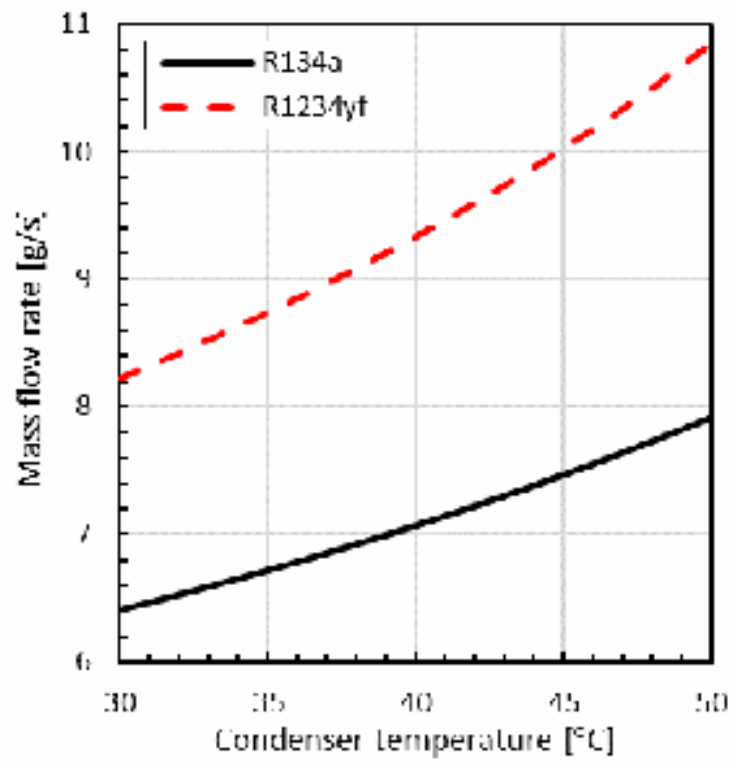

Figure 6b: Variation of the refrigerant mass flow rate versus condenser temperature at $\mathrm{T}_{\text {evap }}=-10^{\circ} \mathrm{C}$

\section{Variation of pressure ratio}

The volumetric efficiency of the compressor is influenced by the pressure ratio. Figure 7a compares both refrigerants pressure ratio at different evaporator temperatures at a condenser temperature of $40^{\circ} \mathrm{C}$. The figure shows that the pressure ratio of $\mathrm{R} 1234 \mathrm{yf}$ lower than that of R134a. As a result, a better volumetric efficiency is expected with R1234yf. Figure 7b shows the variation of the pressure ratio versus the condenser temperature for an evaporator pressure of $-10^{\circ} \mathrm{C}$. The figure highlights the same observation.

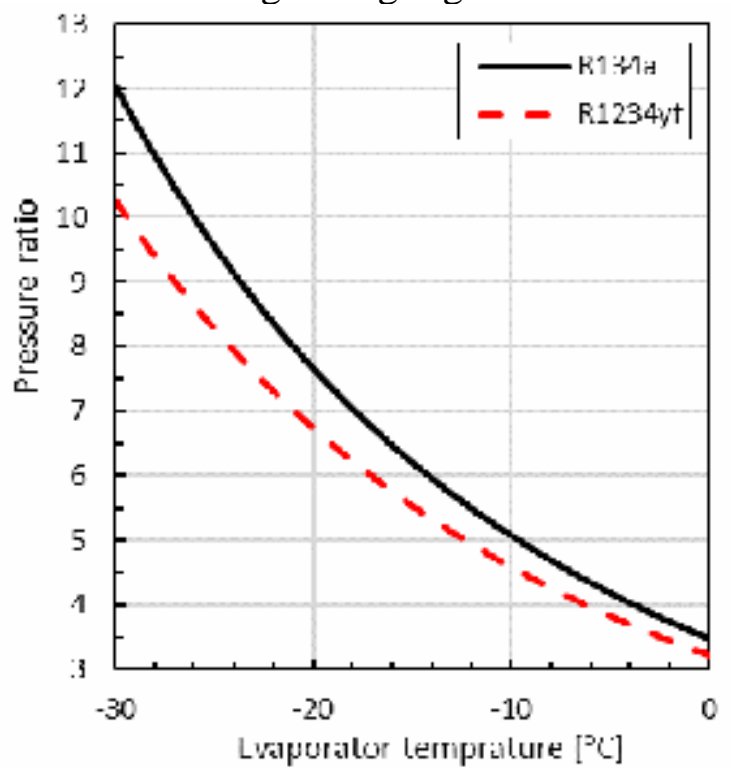

Figure 7a: Variation of pressure ratio against evaporator temperature at $\mathrm{T}_{\text {cond }}=40^{\circ} \mathrm{C}$

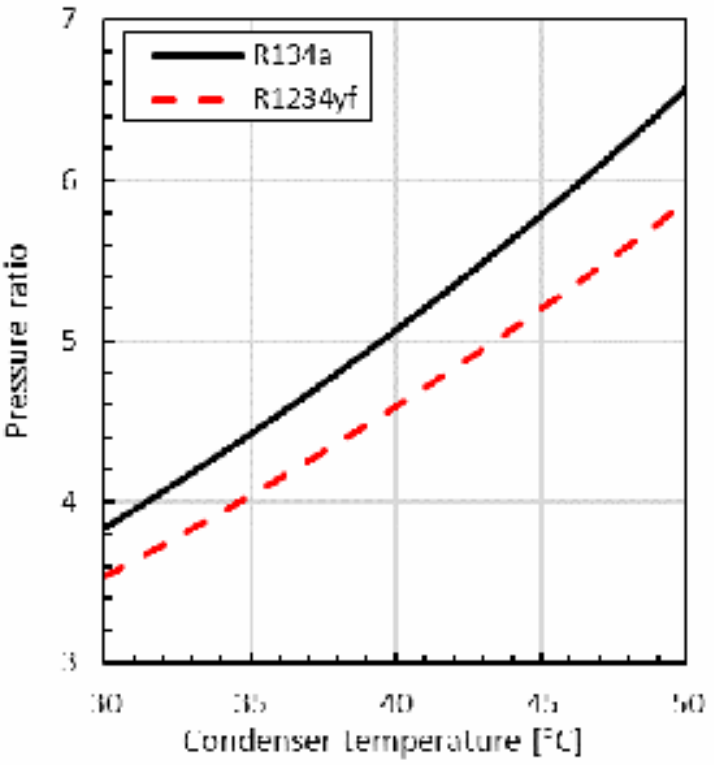

Figure 7b: Variation of pressure ratio against condenser temperature at $\mathrm{T}_{\text {evap }}=-\mathbf{1 0}^{\circ} \mathrm{C}$

\section{Variation of volumetric cooling capacity (VCC)}

The VCC is the one of the most influential factors to be considered when choosing a substitute refrigerant. This is due to the fact that the size of the compressors depends on the VCC. Figure 8a presents the variation of the refrigerants VCC at different evaporator temperatures at a condenser temperature of $40^{\circ} \mathrm{C}$. The figure shows that the VCC of R1234yf 
is very close to that of $\mathrm{R} 134 \mathrm{a}$, within the studied temperature range. The figure also shows that the $\mathrm{VCC}$ of both refrigerants increases with the increase in the evaporator temperature. Figure $8 \mathrm{~b}$ shows that at an evaporator temperature of $-10^{\circ} \mathrm{C}$, the maximum deviations in VCC for 30,40 and $50^{\circ} \mathrm{C}$ condensing temperatures are $2.69 \%, 5.36 \%$ and $8.77 \%$, respectively. Figures $8 \mathrm{a}$ and $\mathrm{b}$ shows that R1234yf can be used as drop-in replacement without major modifications.

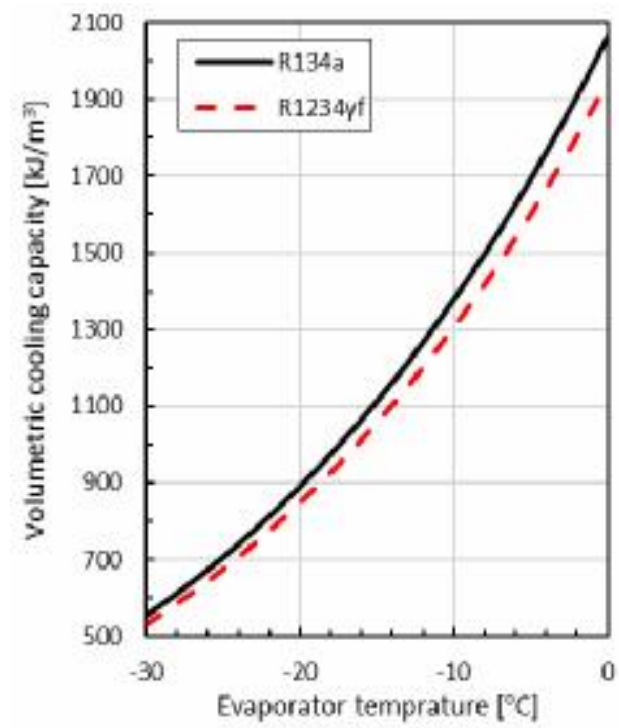

Figure 8a: Variation of volumetric cooling capacity against evaporator temperature at $\mathrm{T}_{\text {cond }}=40^{\circ} \mathrm{C}$

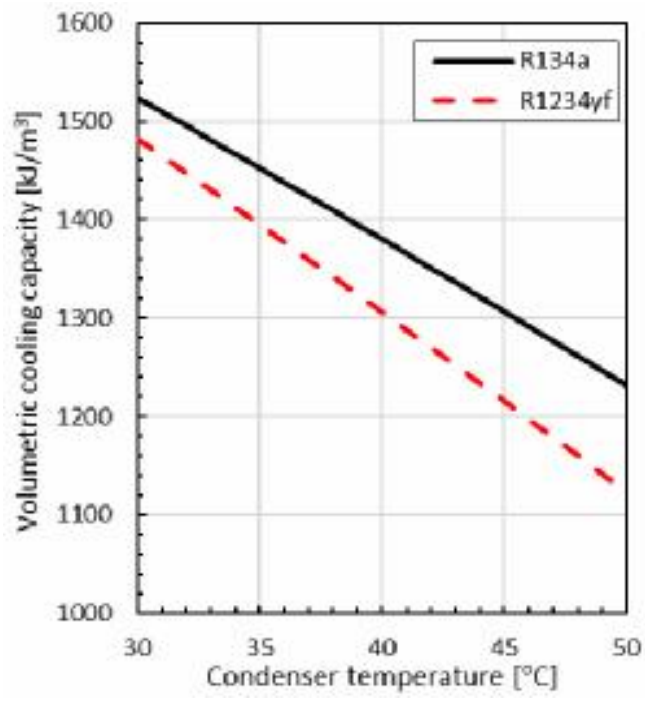

Figure 8b: Variation of volumetric cooling capacity against condenser temperature at $T_{\text {evap }}=-10^{\circ} \mathrm{C}$

\section{Variation of compressor power consumption}

Figure 9a presents the variation of the compressor's power consumption at different evaporator temperatures at a condenser temperature of $40^{\circ} \mathrm{C}$. The figure shows that the compressor power consumption of R1234yf is greater than that of R134a, within the studied temperature range. Figure 11b shows that at an evaporator temperature of $-10^{\circ} \mathrm{C}$, the power consumption of R1234yf is higher than that of R134a by $3.77 \%, 6.00 \%$, and $9.30 \%$ at 30,40 and $50^{\circ} \mathrm{C}$ condensing temperatures, respectively. The power consumption of the refrigerator increases with condenser temperature due to an increase in refrigerant mass flow rate. The figure also shows that the compressor power consumption increases with the condenser temperature due to the increase in the mass flow rate of the refrigerant, as shown in Figure 6 b.

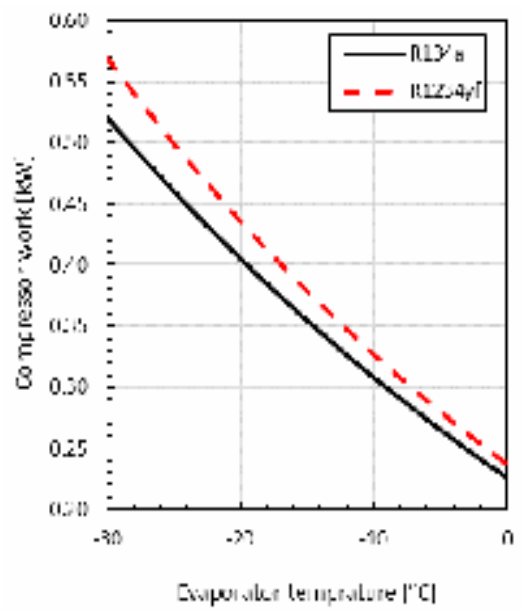

Figure 9a: Variation of the compressor power against evaporator temperature at $\mathrm{T}_{\text {cond }}=40^{\circ} \mathrm{C}$

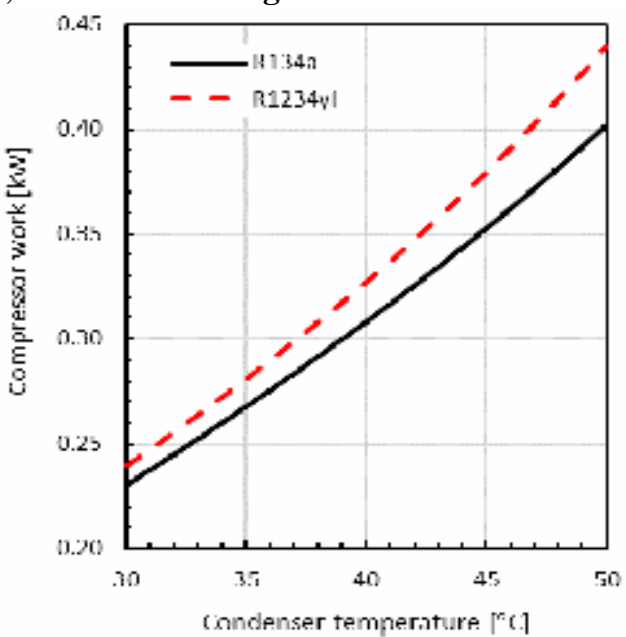

Figure 9b: Variation of the compressor power against condenser temperature at $\mathrm{T}_{\text {evap }}=-\mathbf{1 0}^{\circ} \mathrm{C}$ 


\section{Compressor discharge temperature}

The life of the compressor is greatly affected by the discharge temperature. This is due to the fact that the properties of the compressor lubricant greatly deteriorate at higher compressor discharge temperatures. Figure 10a \& b present the variation of the compressor discharge temperature at different evaporator and condensing temperatures. The figures show that, within the studied temperature range, the compressor discharge temperature of R1234yf is lower than that of R134a. This is due to its lower specific heat ratio. As a result, for R1234yf, the life of the compressor will be greatly increased. The compressor discharge temperature of $\mathrm{R} 1234 \mathrm{yf}$, at an evaporator temperature of $10^{\circ} \mathrm{C}$, is lower than that of $\mathrm{R} 134 \mathrm{a}$ by $9.68^{\circ} \mathrm{C}$, $11.52^{\circ} \mathrm{C}$ and $13.09^{\circ} \mathrm{C}$, at 30,40 and $50^{\circ} \mathrm{C}$ condensing temperatures, respectively.

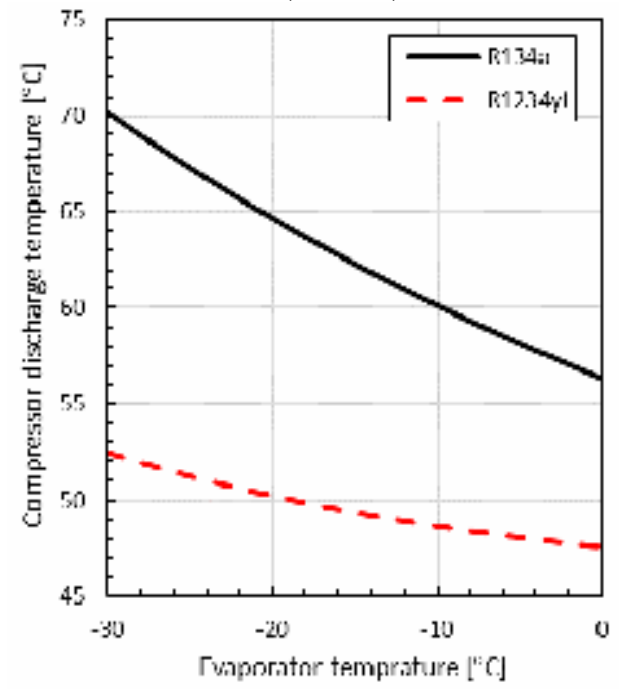

Figure 10a: Variation of the compressor discharge temperature against evaporator temperature at $\mathrm{T}_{\text {cond }}=40^{\circ} \mathrm{C}$

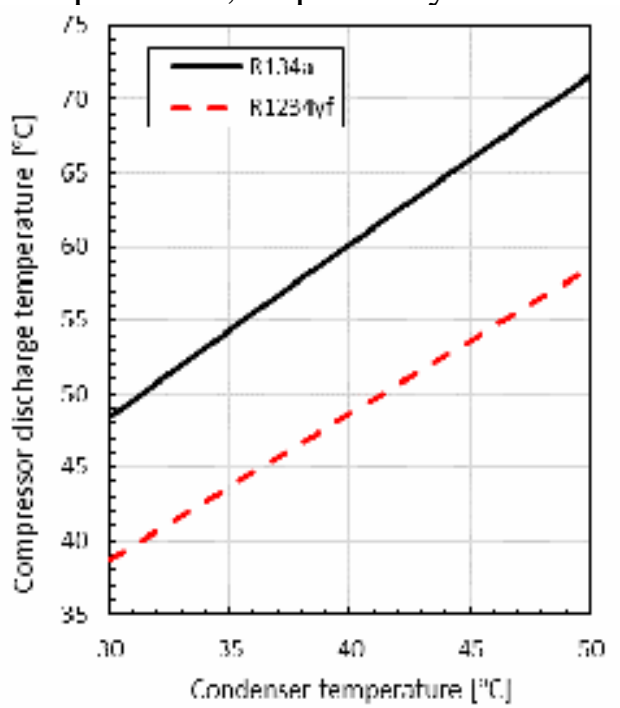

Figure 10b: Variation of the compressor discharge temperature against condenser temperature at $\mathrm{T}_{\text {evap }}=-10^{\circ} \mathrm{C}$

Variation of the coefficient of performance (COP)

The COP of the two refrigerants, at different evaporator temperatures, at a condenser temperature of $40^{\circ} \mathrm{C}$ are compared in Figure 11a. The COP of R1234yf is lower than that of $\mathrm{R} 134 \mathrm{a}$ by about $6.41 \%$, within the studied temperature range. The COP of both R134a and $\mathrm{R} 1234 \mathrm{yf}$ increases by about $57.45 \%$ with an increase in the evaporator temperature from -30 to $0^{\circ} \mathrm{C}$. Figure $11 \mathrm{~b}$ shows that at an evaporator temperature of $-10^{\circ} \mathrm{C}$, the COP of R1234yf is lower than that of $\mathrm{R} 134 \mathrm{a}$ by about $3.59 \%, 5.67 \%$ and $8.54 \%$ at 30,40 and $50^{\circ} \mathrm{C}$, respectively. This due to its higher compressor power consumption and lower evaporator capacity.

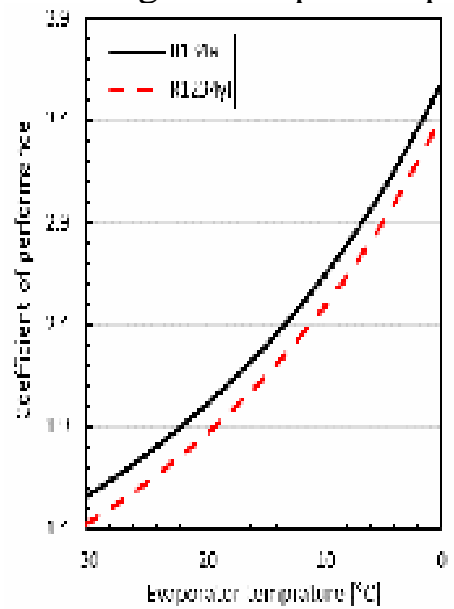

Figure 11a: Variation of COP against evaporator temperature at $\mathbf{T}_{\text {cond }}=$ $40^{\circ} \mathrm{C}$

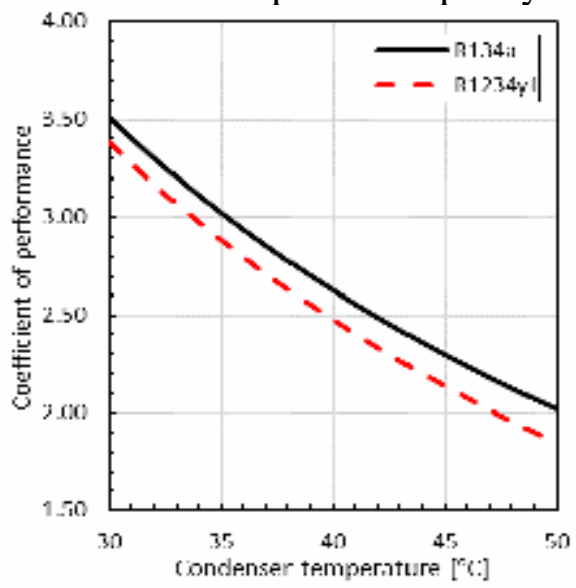

Figure 11b: Variation of COP against condenser temperature at $\mathrm{T}_{\text {evap }}=-10^{\circ} \mathrm{C}$ 


\section{Second law analysis}

Figure 12a \& b compares the total irreversibility at different evaporator and condenser temperatures, for the refrigerants under investigation. The figure shows that R134a has the lowest irreversibility. The figure also shows that the irreversibility increases as the condenser temperature increases and/or the evaporator temperature decreases.

The maximum/minimum irreversibility for both R134a and R1234yf, at a condenser temperature of $40^{\circ} \mathrm{C}$, are $238 / 170 \mathrm{~W}$ and $341 / 192 \mathrm{~W}$, respectively. The reported maximum/minimum irreversibility for both refrigerants is at an evaporator temperature $-30^{\circ} \mathrm{C}$ $10^{\circ} \mathrm{C}$. The maximum irreversibility for R 1234 yf is higher by $43.17 \%$ while the minimum is higher by $12.92 \%$.

At an evaporator temperature of $-10^{\circ} \mathrm{C}$, the maximum/minimum irreversibility for both $\mathrm{R} 134 \mathrm{a}$ and R1234yf, are 367/13 W and 445/32 W, respectively. The reported maximum/minimum irreversibility for both refrigerants is at a condenser temperature $50^{\circ} \mathrm{C} / 30^{\circ} \mathrm{C}$. The maximum irreversibility for R1234yf is higher by $135.74 \%$ while the minimum is higher by $20.73 \%$.

Figure 13a \& b compares the exergetic efficiency at different evaporator and condenser temperatures, for the refrigerants under investigation. The figure shows that R134a has the highest exergetic efficiency followed by R1234yf. In addition, the figures show that the exergy efficiency decreases as the condenser temperature increases and/or the evaporator temperature decreases. This is due to the increase in the compressor specific power, due to the increase in pressure ratio.

The maximum/minimum exergetic efficiency for both R134a and R1234yf, at a condenser temperature of $40^{\circ} \mathrm{C}$, are $32 / 26 \%$ and $29 / 25 \%$, respectively. The reported maximum/minimum exergetic efficiency for both refrigerants is at an evaporator temperature $-30^{\circ} \mathrm{C} / 0^{\circ} \mathrm{C}$. The maximum exergetic efficiency for R1234yf is lower than that for R134a by $4.36 \%$ while the minimum is lower by $8.63 \%$.

At an evaporator temperature of $-10^{\circ} \mathrm{C}$, the maximum/minimum exergetic efficiency for both $\mathrm{R} 134 \mathrm{a}$ and R1234yf, are 40/23\% and 39/21\%, respectively. The reported maximum/minimum exergetic efficiency for both refrigerants is at a condenser temperature $30^{\circ} \mathrm{C} / 50^{\circ} \mathrm{C}$. The maximum exergetic efficiency for R $1234 \mathrm{yf}$ is lower by $3.58 \%$ while the minimum is higher by $8.50 \%$.

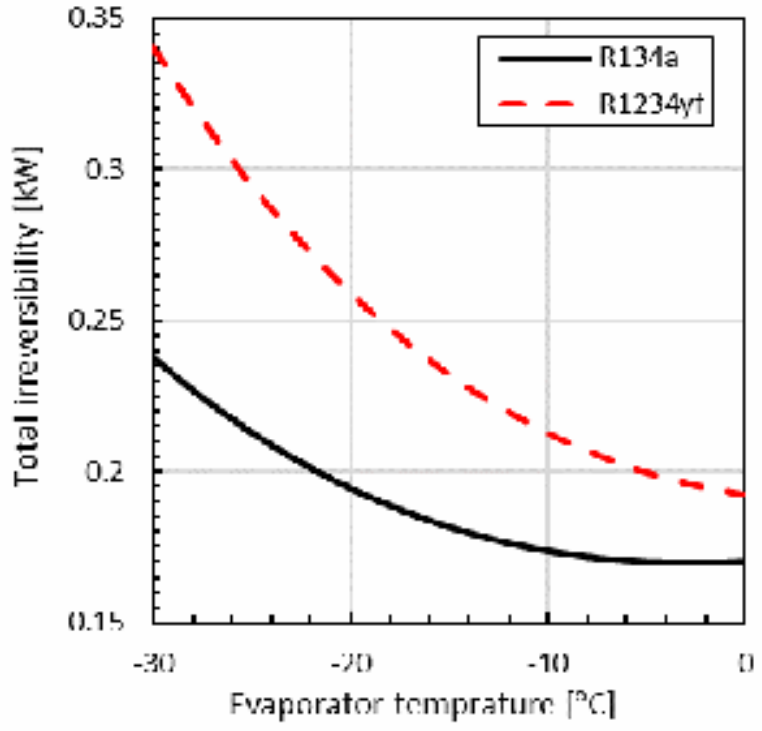

Figure 12a: Variation of the total irreversibility against evaporator temperature at $\mathrm{T}_{\text {cond }}=40^{\circ} \mathrm{C}$

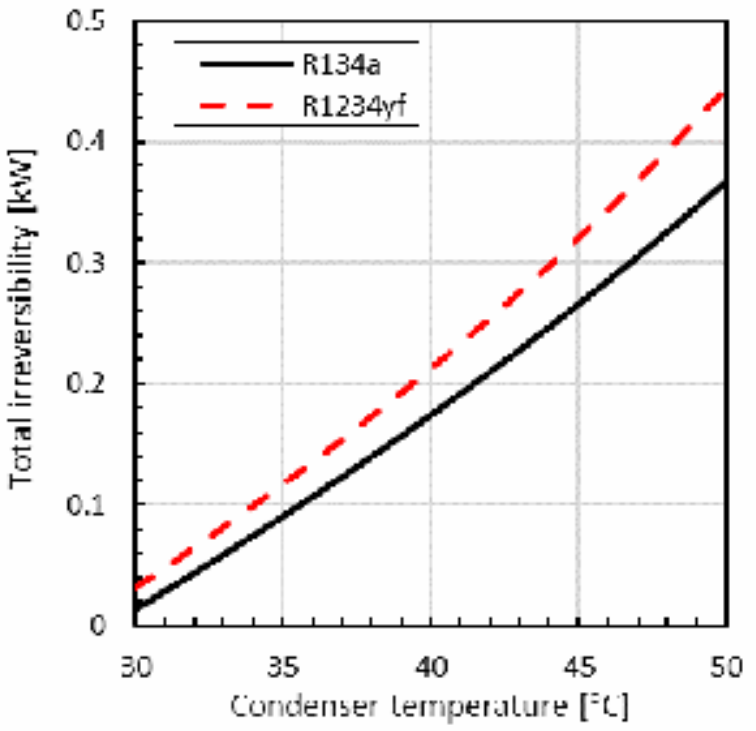

Figure 12b: Variation of the total irreversibility against condenser temperature at $\mathrm{T}_{\text {evap }}=-\mathbf{1 0}^{\circ} \mathrm{C}$ 


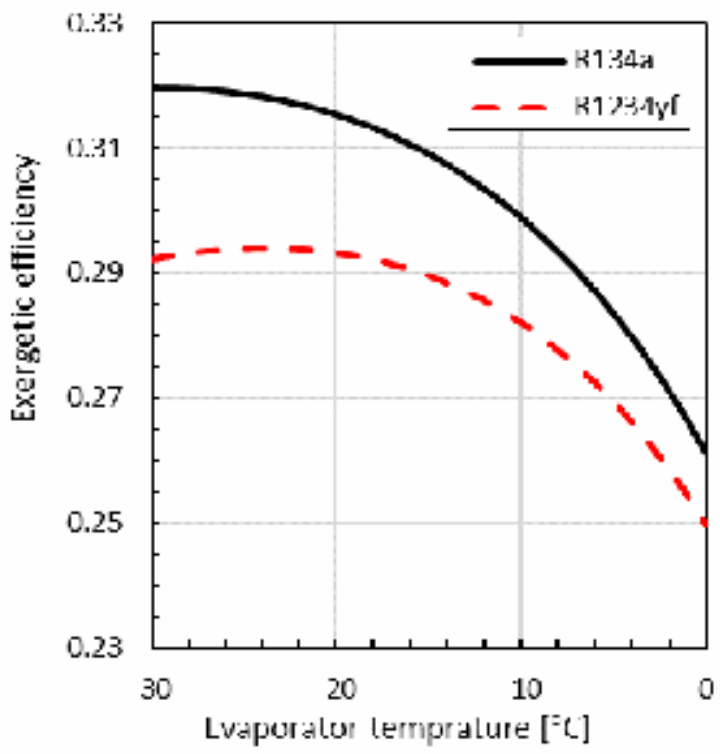

Figure 13a: Variation of the exergetic efficiency against evaporator temperature at $\mathrm{T}_{\text {cond }}=40^{\circ} \mathrm{C}$

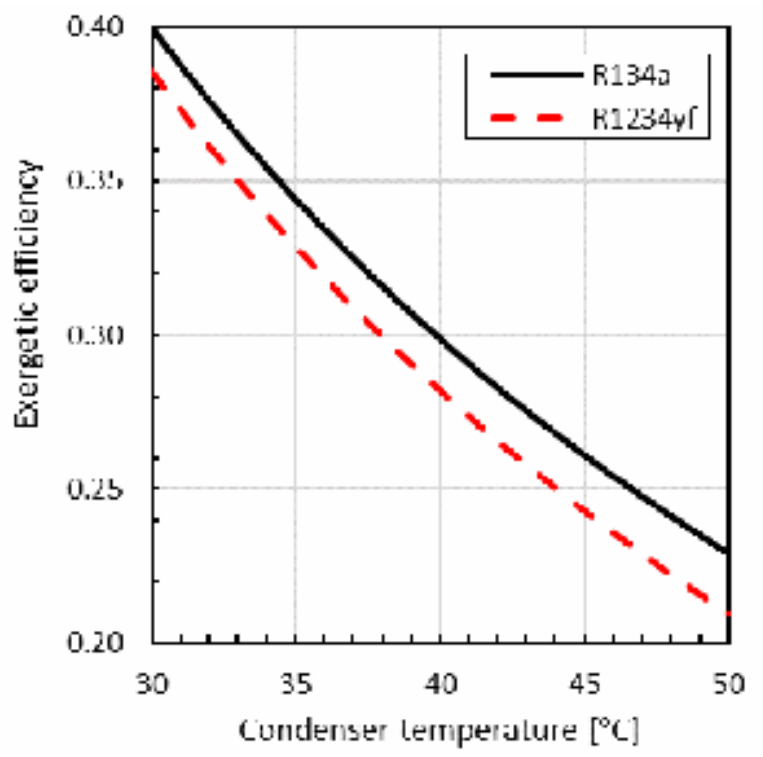

Figure 13b: Variation of the exergetic efficiency against condenser temperature at $\mathrm{T}_{\text {evap }}=-\mathbf{- 1 0}^{\circ} \mathrm{C}$

Figure 14 a $\&$ b shows the variation of the second law efficiency, at different evaporator and condenser temperatures, for the refrigerants under investigation. Increasing the evaporator temperature or decreasing the condenser pressure increase both the coefficient of cooling performance, as shown in Figure 14, and the Carnot efficiency, as shown by equation (19). As the temperature lift approaches zero, the Carnot efficiency increases dramatically tending to infinity. As a result, the second law efficiency tends to zero.

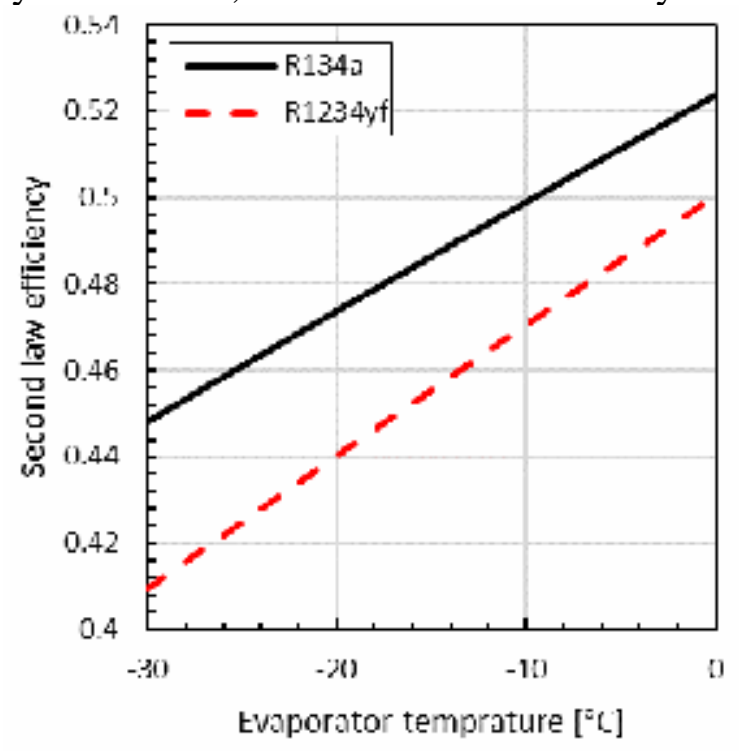

Figure 14a: Variation of the second law efficiency against evaporator temperature at $T_{\text {cond }}=40^{\circ} \mathrm{C}$

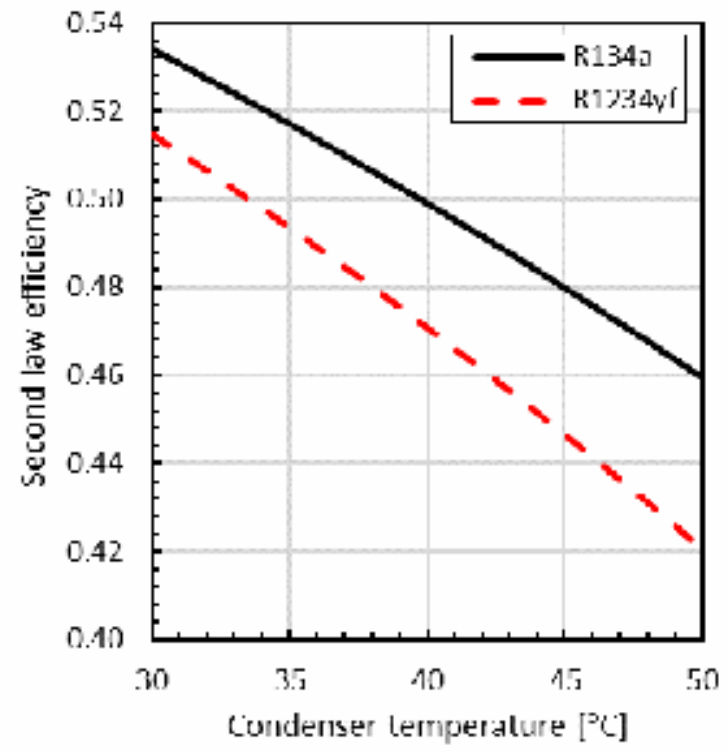

Figure 14b: Variation of the second law efficiency against condenser temperature at $\mathrm{T}_{\text {evap }}=-10^{\circ} \mathrm{C}$

\section{CONCLUSIONS}

This study presents a theoretical energetic and exergetic comparison for the performance of a vapor compression refrigeration system using R134a and R1234yf. R134a is used in the analysis as a reference refrigerant. A parametric study is performed to analyze the effect of the ambient and the evaporating temperatures on the performance of the vapor compression cycle. The results show that the maximum deviation in VCC of R1234yf is $8.81 \%$. Also, the compressor power consumption of R1234yf is greater than that of R134a by an average of 
7.07\%. Consequently, the COP of R1234yf is lower than that of R134a by about $6.56 \%$. Hence, R1234yf can be used as drop-in substitute without major modification in the existing R134a systems.

\section{REFERENCES}

[1] UNEP, "Montreal Protocol on Substances that Deplete the Ozone Layer. United Nations Environment Program, New York, USA.," 1987.

[2] E. Johnson, "Global warming from hfc," Environ. Impact Assess. Rev., vol. 18, no. 6, pp. 485-492, Nov. 1998.

[3] B. O. Bolaji and Z. Huan, "Performance investigation of some hydro-fluorocarbon refrigerants with low global warming as substitutes to R134a in refrigeration systems," J. Eng. Thermophys., vol. 23, no. 2, pp. 148-157, 2014.

[4] A. G. Deveciołlu and V. Oruç, "Characteristics of Some New Generation Refrigerants with Low GWP," Energy Procedia, vol. 75, pp. 1452-1457, 2015.

[5] J. M. Belman-Flores, A. P. Rodríguez-Muñoz, C. G. Pérez-Reguera, and A. MotaBabiloni, "Experimental study of R1234yf as a drop-in replacement for R134a in a domestic refrigerator," Int. J. Refrig., vol. 81, pp. 1-11, Sep. 2017.

[6] C. Aprea, A. Greco, and A. Maiorino, "An experimental investigation on the substitution of HFC134a with HFO1234YF in a domestic refrigerator," Appl. Therm. Eng., vol. 106, pp. 959-967, Aug. 2016.

[7] C. Aprea, A. Greco, and A. Maiorino, "An experimental investigation of the energetic performances of HFO1234yf and its binary mixtures with HFC134a in a household refrigerator," Int. J. Refrig., vol. 76, pp. 109-117, Feb. 2017.

[8] K. Harby, "Hydrocarbons and their mixtures as alternatives to environmental unfriendly halogenated refrigerants: An updated overview," Renew. Sustain. Energy Rev., vol. 73, pp. 1247-1264, 2017.

[9] A. R. El-Sayed, M. El Morsi, and N. A. Mahmoud, "A Review of the Potential Replacements of HCFC/HFCs Using Environment-Friendly Refrigerants," Int. J. AirConditioning Refrig., vol. 26, no. 03, p. 1830002, Sep. 2018.

[10] B. O. Bolaji, "Experimental study of R152a and R32 to replace R134a in a domestic refrigerator," Energy, vol. 35, no. 9, pp. 3793-3798, 2010.

[11] H. Cho and C. Park, "Experimental investigation of performance and exergy analysis of automotive air conditioning systems using refrigerant R1234yf at various compressor speeds," Appl. Therm. Eng., vol. 101, pp. 30-37, 2016.

[12] P. Ortega Sotomayor and J. A. R. Parise, "Characterization and simulation of an open piston compressor for application on automotive air-conditioning systems operating with R134a, R1234yf and R290," Int. J. Refrig., vol. 61, pp. 100-116, 2016.

[13] S. Golzari, A. Kasaeian, S. Daviran, O. Mahian, S. Wongwises, and A. Z. Sahin, "Second law analysis of an automotive air conditioning system using HFO-1234yf, an environmentally friendly refrigerant," Int. J. Refrig., vol. 73, pp. 134-143, Jan. 2017.

[14] C. S. Rajamanickam, C. P. Karthikeyan, and A. A. Samuel, "Influence of refrigerant (R134a/R1234yf) properties on cooling performance of an automobile Hvac," Int. J. Appl. Eng. Res., vol. 11, no. 5, pp. 3703-3707, 2016.

[15] D. Sánchez, R. Cabello, R. Llopis, I. Arauzo, J. Catalán-Gil, and E. Torrella, "Energy performance evaluation of R1234yf, R1234ze(E), R600a, R290 and R152a as lowGWP R134a alternatives," Int. J. Refrig., vol. 74, pp. 269-282, Feb. 2017.

[16] J. Shi, C. Liu, J. Hu, Y. Zhao, and J. Chen, "Experimental research and optimization on the environmental friendly R1234yf refrigerant in automobile air conditioning system," J. Shanghai Jiaotong Univ., vol. 21, no. 5, pp. 548-556, 2016.

[17] Z. Janković, J. Sieres Atienza, and J. A. Martínez Suárez, "Thermodynamic and heat transfer analyses for R1234yf and R1234ze(E) as drop-in replacements for R134a in a small power refrigerating system," Appl. Therm. Eng., vol. 80, pp. 42-54, 2015.

[18] A. Sethi, E. Vera Becerra, and S. Yana Motta, "Low GWP R134a replacements for small refrigeration (plug-in) applications," Int. J. Refrig., vol. 66, pp. 64-72, 2016.

[19] J. Sieres and J. M. Santos, "Experimental analysis of R1234yf as a drop-in replacement for R134a in a small power refrigerating system," Int. J. Refrig., vol. 91, pp. 230-238, Jul. 2018. 
[20] Z. Meng, H. Zhang, M. Lei, Y. Qin, and J. Qiu, "Performance of low GWP R1234yf/R134a mixture as a replacement for R134a in automotive air conditioning systems," Int. J. Heat Mass Transf., vol. 116, pp. 362-370, Jan. 2018.

[21] C. D. Needham and P. R. Westmoreland, "Combustion and flammability chemistry for the refrigerant HFO-1234yf (2,3,3,3-tetrafluroropropene)," Combust. Flame, vol. 184, pp. 176-185, Oct. 2017.

[22] B. Feng, Z. Yang, and R. Zhai, "Experimental study on the influence of the flame retardants on the flammability of R1234yf," Energy, vol. 143, pp. 212-218, Jan. 2018.

[23] M. Koban, "HFO-1234yf low GWP refrigerant LCCP analysis," p. 2014, Apr. 2009.

[24] M. O. Lemmon, E.W., Huber, M.L., McLinden, "NIST Standard Reference Database 23: Reference Fluid Thermodynamic and Transport Properties-REFPROP." National Institute of Standards and Technology, Standard Reference Data Program, Gaithersburg, 2013.

[25] "EES: Engineering Equation Solver |F-Chart Software : Engineering Software." .

[26] R. E. S. Claus Borgnakke, Fundamentals of Thermodynamics. Wiley, 2012.

[27] C. Wu, Thermodynamics and Heat Powered Cycles: A Cognitive Engineering Approach. Nova Publishers, 2007.

[28] "Household refrigerator-freezers - characteristics and test methods. ISO 8187." International Standards Organization, Geneva, Switzerland, pp. 1-52, 1991. 